\title{
Do people prefer natural landscapes? An empirical study in Chile
}

\author{
¿La gente prefiere paisajes naturales? Un estudio empírico en Chile
}

\author{
Laura Nahuelhual a,b*, Pedro Laterra ${ }^{c}$, Dana Jiménez ${ }^{\mathrm{d}}$, Andrea Báez ${ }^{\mathrm{e}}$, \\ Christián Echeverría ${ }^{\mathrm{f}, \mathrm{g}}$, Rodrigo Fuentes ${ }^{\mathrm{f}}$
}

* Autor de correspondencia: a Universidad Austral de Chile, Facultad de Ciencias Agrarias, Instituto de Economía Agraria, 2o piso, casilla 567, Valdivia, Chile, tel.: 56-63-2221237, lauranahuel@uach.cl

${ }^{\mathrm{b}}$ Centro de Investigación en Dinámica de Ecosistemas Marinos de Altas Latitudes (IDEAL), Chile.

${ }^{\mathrm{c}}$ Consejo Nacional de Investigaciones Científicas y Técnicas (CONICET) - Fundación Bariloche,

Av. Bustillo 9500, 8400 San Carlos de Bariloche, Argentina.

${ }^{\mathrm{d}}$ Centro de Ciencia del Clima y la Resiliencia (CR2), Chile.

${ }^{\mathrm{e}}$ Universidad Austral de Chile, Facultad de Ciencias Económicas, Instituto de Estadística, Valdivia, Chile.

${ }_{\mathrm{f}}^{\mathrm{f} U n i v e r s i d a d ~ d e ~ C o n c e p c i o ́ n, ~ F a c u l t a d ~ d e ~ C i e n c i a s ~ F o r e s t a l e s, ~ L a b o r a t o r i o ~ d e ~ E c o l o g i ́ a ~ d e ~ P a i s a j e, ~ V i c t o r i a ~ 631, ~ C o n c e p c i o ́ n, ~ C h i l e . ~}$

${ }^{g}$ Millennium Nucleus Center for the Socioeconomic Impact of Environmental Policies (CESIEP), Santiago, Chile.

\section{SUMMARY}

There is a growing consciousness that the viability of landscape-related policy depends on support from the general public. However, during planning stages, knowledge regarding landscape perceptions and preferences of people is generally absent or limited. This study presents an observer-based landscape assessment, applying a physical landscape attribute approach to measure visual preferences based on photographs. Data on age, gender, place of residence, income and education level were collected by means of a country-wide online questionnaire $\left(\mathrm{n}^{\circ}\right.$ answers $=643$ ), along with information from respondents on visual evaluations of images depicting various compositions and levels of scenic beauty of rural landscapes of south-central Chile. The effects of landscape composition and scenic beauty on responses (individual ratings), as well as the interaction effects between those attributes and personal characteristics, were tested by applying multivariate repeated measures ANOVA and Wilks multivariate tests. Ratings for both scenic beauty and landscape composition significantly varied across photographs, revealing a clear preference for landscapes dominated by native vegetation over landscapes dominated by exotic tree plantations or cultivated lands. A relatively low, nonetheless significant, portion of the rating variability was explained by subtle differences in preferences arising from personal characteristics. Results contribute to several recent efforts to understand public opinion regarding natural and rural landscape changes. Specifically, results sustain the adverse effects of loss of natural habitats on people's appraisals of rural landscapes.

Key words: landscape change, landscape values, social preferences, landscape evaluation, landscape planning.

\section{RESUMEN}

Existe una conciencia creciente de que la viabilidad de la planificación del paisaje depende del apoyo del público. Sin embargo, el conocimiento sobre percepciones y preferencias del público es generalmente limitado. Este estudio presenta una evaluación del paisaje basada en el observador y atributos físicos del paisaje. Para ello se aplicó un cuestionario en línea ( $\mathrm{n}^{\circ}$ respuestas $=643$ ), a partir del cual se recolectó información sobre edad, género, lugar de residencia, nivel de ingresos y nivel educativo, y sobre las preferencias de los encuestados por diversas composiciones y niveles de belleza escénica de paisajes rurales del centro-sur de Chile, usando fotografías. Se analizaron los efectos de la composición y la belleza escénica sobre las respuestas (calificaciones individuales), así como los efectos de interacción entre esos atributos y características personales de los entrevistados mediante la aplicación de medidas multivariadas de repetición ANDEVA y prueba multivariada de Wilks. Las calificaciones tanto de la belleza escénica como de la composición del paisaje varían significativamente entre las fotografías, lo que revela una clara preferencia por paisajes dominados por vegetación nativa sobre paisajes dominados por plantaciones de árboles exóticos o tierras cultivadas. Una porción relativamente baja pero significativa de la variabilidad se explicó por diferencias en las preferencias derivadas de las características personales. Los resultados contribuyen a varios esfuerzos recientes para comprender la opinión pública sobre los cambios del paisaje rural. Específicamente, los resultados respaldan los efectos adversos de la pérdida de hábitats naturales en las apreciaciones de las personas.

Palabras clave: transformación del paisaje, valores del paisaje, preferencias sociales, evaluación del paisaje, ordenamiento territorial. 


\section{INTRODUCTION}

Provision of high-quality landscapes is gradually declining worldwide as a consequence of the degradation caused by competing activities of various magnitudes and types. At the same time, societal demand for new functions and meanings of rural landscapes and natural spaces (e.g. ecosystem services supply) is changing and diversifying (van der Wal et al. 2014). In this context, there is a growing consciousness that the viability of landscape-related policy will also depend on support from the general public (Sevenant and Antrop 2010). However, during planning stages, knowledge regarding public perceptions and preferences on landscape is generally absent or limited.

To analyze the consequences of landscape change in planning and policy evaluation, it is important to assess landscapes and to consider the observer's experience to understand these changes (Tveit et al. 2006).

Assessment of landscape perceptions and preferences is also a critical aspect in the construction of cultural ecosystem services indicators (Casado-Arzuaga et al. 2014). Recreation opportunities, for example, reflect a combination of activities according to particular settings. In turn, one could say that recreational choices reflect the importance that people place on a recreational experience, which depends on a series of personal characteristics (age, social and cultural background, attitudes and values, etc.) - factors that are directly related to the observer and indirectly to the landscape (Brown 2013, Scholte et al. 2015). Sense of place, as another cultural service, is the result of a particular setting and the experiences of an individual within that setting. People appreciate different types of landscapes, as well as different ecosystems within landscapes, according to temporal and spatial scales and purposes, accessing a "portfolio of places" that is particular to each person (Lock and Cole 2011).

Landscapes cannot be defined considering their individual components alone, but are integrated wholes; a construct of the mind and of senses and feelings, where the landscape objects and the observer become indivisible (Muñoz-Pedreros 2017). Theories of landscape aesthetics suggest that the content and spatial arrangement of landscape attributes could be used to predict landscape preferences (e.g. Tveit et al. 2006). Different studies based on personal interviews and photographs show that by altering the biophysical attributes in the images, the impact of these attributes on preference can be objectively measured through preference scores (Ode et al. 2009, Van Berkel and Verburg 2014). Landscape preferences appear to be influenced by the observer's personal characteristics and social factors (Sevenant and Antrop 2010, Van Berkel and Verburg 2014, van Zanten et al. 2014, Surová and PintoCorreia 2016).

Usually, landscape assessment focuses on certain groups of people, which may be due to the increasing difficulty of the dataset, when a variation both in landscape attributes and features of respondents is to be included in the models (Sevenant and Antrop 2010). In this sense, internet-based surveys are increasingly used for data collection, because application is simple and cheap and also they allow instant access to a large group of respondents (Greenacre 2016). A landscape evaluation can be defined as the comparative relationships between two or more landscapes in terms of assessment of visual quality (Laurie 1975). In turn, landscapes can be classified as either natural or cultural; however, the level of naturalness may be debatable in territories characterized by a wide variety, ranging from pristine landscapes to urban landscapes, and thus it is a vague classification (Muñoz-Pedreros 2017). In turn, landscape as perceived by humans can be classified into spatial configurations and specific elements of landscape (Kaplan and Kaplan 1989). Spatial configurations are related to the organization and composition of the landscape elements, and influenced by the depth and breadth of view (Nielsen et al. 2012). On the other hand, specific elements emphasize experience and interaction, paying special attention to distinctive elements and subtle details. Visual perception may vary in the terms used, consequently can be called visual quality in cities and scenic beauty in rural areas (Muñoz-Pedreros 2004).

This study presents an observer-based evaluation, applying a physical landscape attribute approach (e.g. Dachary-Bernard and Rambonilaza 2012) to measure visual preferences based on photographs of rural landscapes. Landscape composition and scenic beauty were chosen as the main attributes for the assessment. Landscape composition attributes (e.g. land cover patterns) are often regarded as a combined result of anthropogenic and biophysical processes - biotic and abiotic. Scenic beauty in turn was represented by attributes that describe the visual aspects of the landscape biophysical features (e.g. presence of water bodies, hills and volcanoes) (van Zanten et al. 2014).

An underlying hypothesis of the study is that people, despite their individual characteristics, prefer landscapes with a mixed composition over landscapes dominated by a single land cover and use. The goal is to explore, based on statistical methods, how personal characteristics, namely education, age, income, gender and place of residence, may affect visual ratings for various landscape compositions and different levels of scenic beauty. It is important to mention however that this study does not aim at providing unbiased estimates of population parameters, nonetheless focuses on exploring the relationships between variables to understand people's characteristics that influence their preferences on certain attributes of landscape.

Public perception-based approaches (Wang et al. 2016) to assessing landscape quality have been actively used in landscape assessment studies, complementing the shortcomings of expert-led approaches (Schirpke et al. 2013). The use of photographs in preference surveys is an established substitute for the real landscape (e.g. Ode et al. 2009).

However, most studies have been conducted in developed countries, and Europe in particular, where landscapes 
as a well as individual characteristics, such as income and education level, differ significantly from those of South American countries. This study is in line with several recent efforts to understand public opinion regarding potential negative effects of natural landscape transformation and the implications this may have for landscape planning (Sevenant and Antrop 2010, Tagliafierro et al. 2016, Lee and Son 2017).

\section{METHODS}

Study area. The study area comprises rural landscapes from south-central Chile (figure 1). The area is located in a transitional climate between the dry-temperate climate of the North and the wet-temperate climate of the South. Rainfall is concentrated over winter with very dry summers. The natural forest is mainly dominated by a secondary forest of Nothofagus spp. and sclerophyllous species. Also, many endangered plant species, including Araucaria araucana (Molina) K. Koch, Nothofagus alessandrii M. Espinosa, Pitavia punctata (Ruiz et Pav.) Molina, Gomortega keule (Molina) H. Baillon, and Austrocedrus chilensis D. Don are present in the study area. The coastal landscape (land located over $200 \mathrm{~m}$ elevation, 19,201 $\mathrm{km}^{2}$ ) is characterized by large-scale deforestation that began in the XVI-XVII ${ }^{\text {th }}$ centuries. At

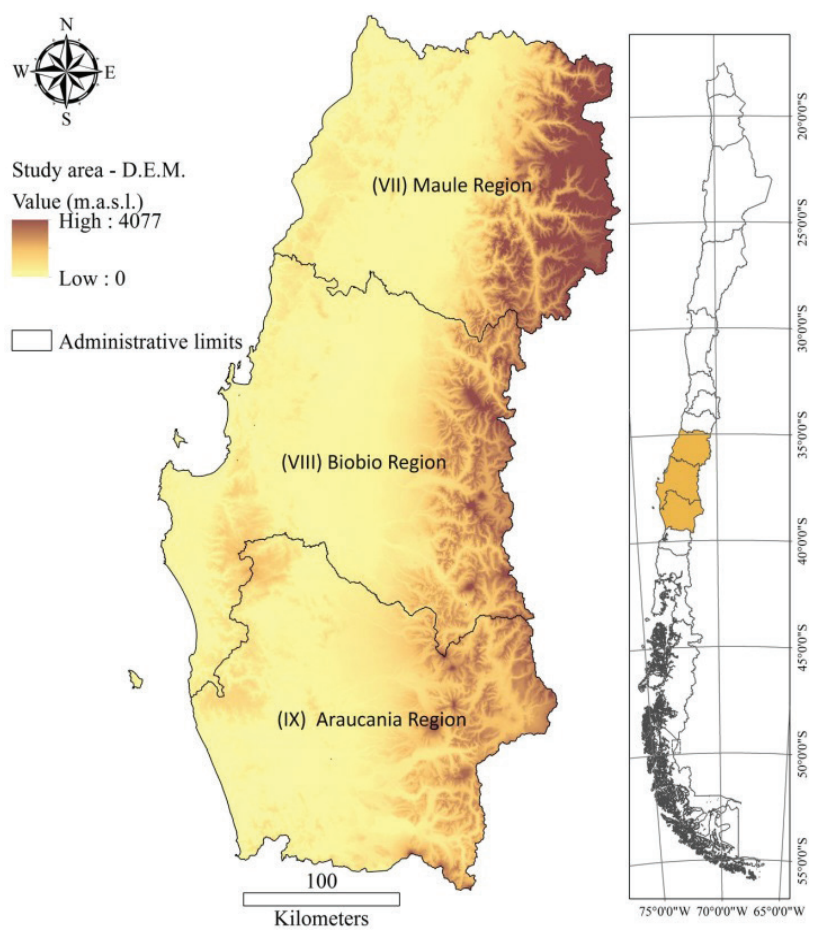

Figure 1. Study area in south-central Chile comprising three administrative regions of Chile: Maule, Biobío and La Araucanía.

Área de estudio en el centro sur de Chile, que cubre tres regiones administrativas de Chile: Maule, Biobío y La Araucanía. present, industrial forest plantations of pines (Pinus radiata D. Don) and eucalyptus (Eucalyptus sp. C. L'Héritier) dominate land use, except in the southern portion, where highly degraded secondary forests surround a protected area with a singular forest of $A$. araucana (Nahuelbuta National Park). In the Andean landscape (land located over 1,000 m a.s.1., 16,921 $\mathrm{km}^{2}$ ), we observe large extents of native forest, with volcanoes in the background, while agricultural land and forest plantations are found in lowland (200-1,000 m). In this landscape, protected areas conserve large extents of $A$. araucana and Nothofagus spp. forests. The landscape of the central zone is characterized mostly by arable agriculture.

Selection of pictures to reflect landscape composition and scenic beauty. The photographs for landscape composition and scenic beauty were selected with the objective of representing an illustrative cross-section of rural landscapes in the study area. It is important to mention that the photographs did not intend to reflect increasing levels of transformation or beauty; rather, they were selected to show the most common compositions and scenic vistas of the study area.

Five researchers of disciplines relating to landscape ecology science in Chile at Universidad de Concepción, with in-depth knowledge of the area, selected the final landscape images from of a larger set of photographs. As an expert process, the issue of image representativeness must be acknowledged. Indeed, if a different group of experts had been asked to select the photographs, a different set of images could have resulted. To ensure reliability in the perception process, pictures with approximately the same resolution conditions were selected (figures 2 and 3).

Questionnaire design. We designed a web-based questionnaire that aimed at eliciting relative ratings for various landscape compositions and scenic beauty within the study area. For landscape composition analyses, satellite images from Google Earth illustrating different land use and cover types were used. The scale used to rate each photo (figure 2) included the following categories: "I like it very much", "I like it", "I like it a little", "Indifferent" and "I do not like it".

The questionnaire was designed to present the photos one by one, not giving the respondent the possibility to go back to previous images. Furthermore, no specific information was provided to respondents regarding the photos to avoid bias. This decision was made based on a pilot testing, which revealed two situations: i) that looking at all pictures simultaneously produced a bias against more transformed landscapes (figure 2D and 2E for example); and ii) that different orderings of the pictures did not influence the ratings. The pilot test was held on May $14^{\text {th }}$ of 2015 with 10 people, including researchers, students and eco-tourists, to improve the general comprehensibility of the questionnaire. 
For scenic beauty analyses, panoramic photographs were used that illustrated elements of the representative landscapes, comprising natural elements such as volcanoes or lakes, to harvested forest plantations, agricultural crops or volcanic rock formations. The elements in the pictures were selected as they were present in all three regions of the study area. The scale used for rating scenic beauty was the same as for landscape composition. As with landscape composition, photos were shown correlatively and the respondent could not go back to a previous photo, nor was information provided regarding the content of the image.

Questionnaire application. The final online questionnaire was sent to people who were engaged through social networks, specifically e-mail, twitter and Facebook, trying to achieve the highest possible diversity. Around 200 persons were contacted via e-mail, whereas the survey link was sent to 60 groups on Facebook and 30 groups on twitter. The selected groups had two features: i) groups from Chile; ii) groups with more than 1,000 followers, with at least one posti in the week previous to the interview. The groups from the study area represented $60 \%$ of total and covered sports followers, groups from municipalities, and different enterprises. Groups associated with mass media ( $\mathrm{TV}$, radio and sport celebrities and actors) comprised $20 \%$ of total. Groups linked to universities and university students represented $10 \%$, and finally political groups comprised $10 \%$.
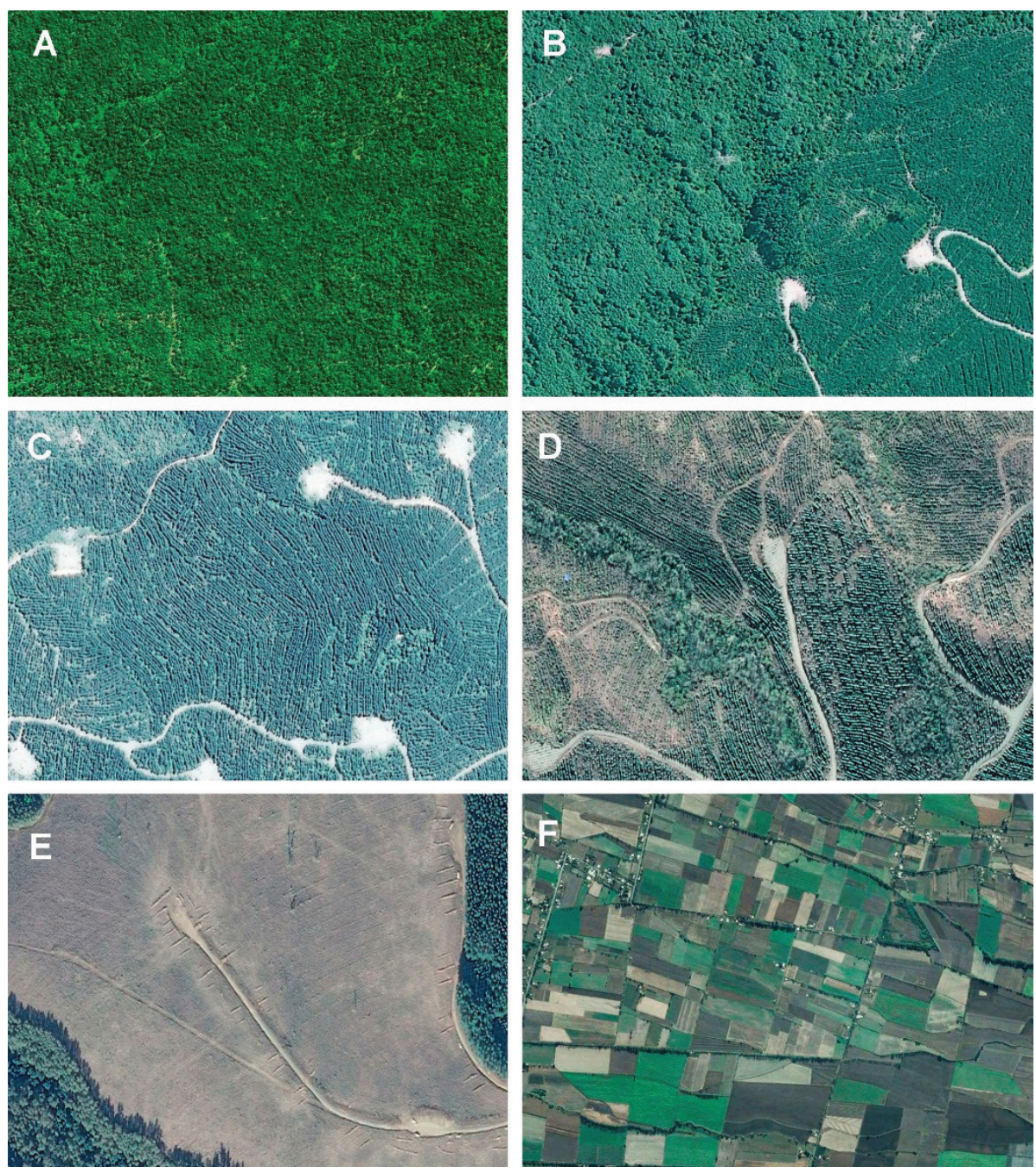

Figure 2. Images presented to respondents showing different landscape compositions: A: Native forest; B: Combination of native forest and industrial plantation of Pinus radiata; C: Adult industrial plantation of P. radiata; D: Young industrial plantation recently harvested (P. radiata); E: Clear-cutting area of industrial plantations (P. radiata); F: Agricultural and pasture lands.

Imágenes presentadas a los encuestados que muestran diferentes composiciones paisajísticas. A: bosque nativo; B: combinación de bosque nativo y plantación industrial de Pinus radiata; $\mathrm{C}$ : plantación industrial adulta de $P$. radiata; D: plantación industrial joven recientemente cosechada ( . radiata); E: área de tala rasa de plantaciones industriales $(P$. radiata); F: terrenos agrícolas y praderas. 

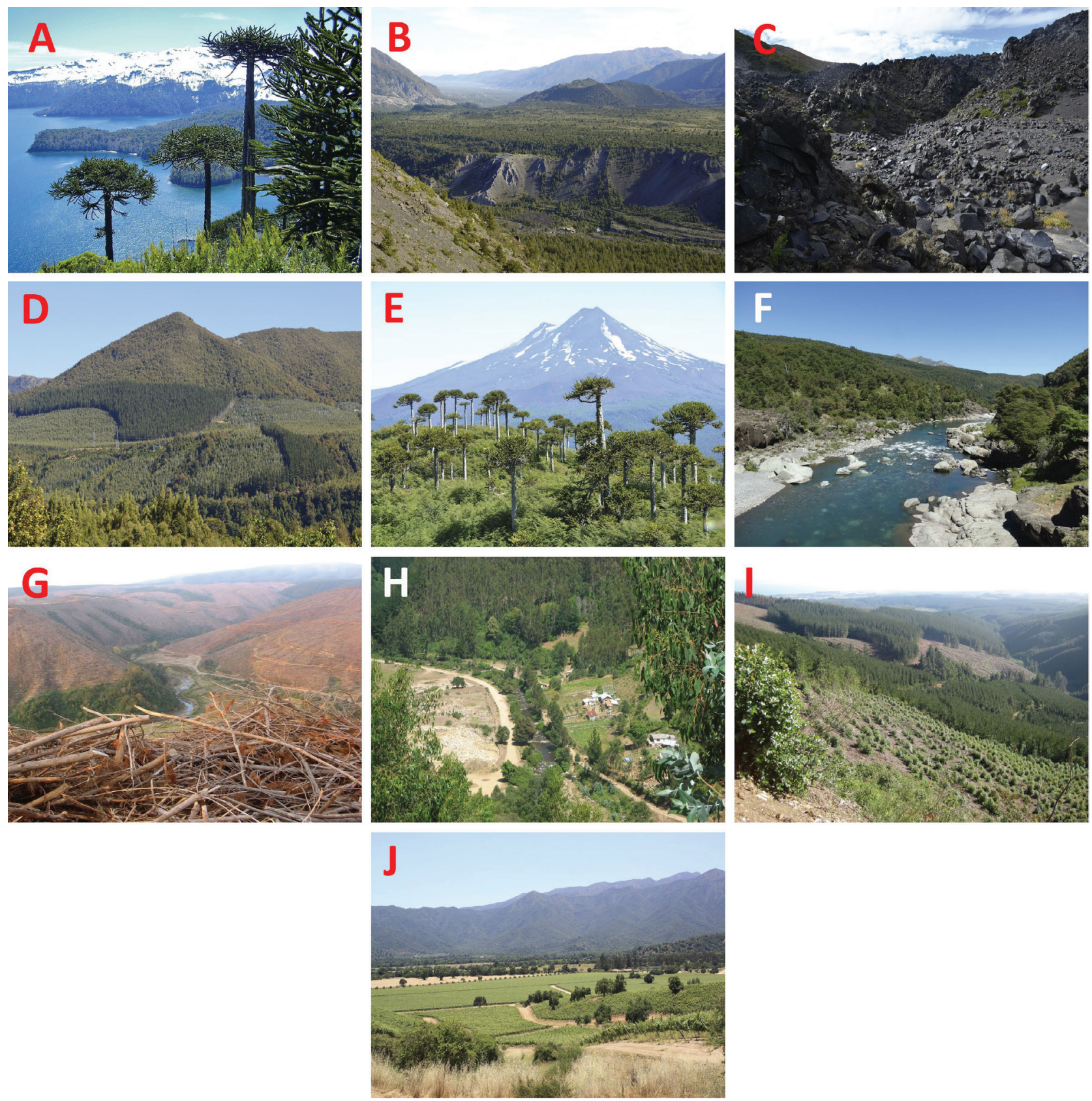

Figure 3. Photographs illustrating levels of scenic beauty. A: Lake, volcanoes and Araucaria araucana trees in the Andes landscape; B: secondary forest in the highland of the Andes landscape; C: Volcanic rocks in highland of the Andes landscape; D: Mosaic of Eucalyptus sp. plantation at different stages of development and native forest in the Pre-Andean area; E: Old-growth A. araucana forest, secondary forest and volcano in the highland of the Andes; F: River, secondary forest with presence of Austrocedrus chilensis trees in the pre-Andes landscape; G: Clear-cutting of P. radiata forest plantation; H: mosaic of agricultural lands, Eucalyptus sp. plantation and farms in the Coastal landscape; I: $P$. radiata plantations at various stages of development; J: Agricultural crops in flat areas and secondary forest in the hills in the pre-Andes.

Fotografías ilustrando los niveles de belleza escénica. A: lago, volcanes y Araucaria araucana en el paisaje de Los Andes; B: bosque secundario en el altiplano del paisaje de Los Andes; C: rocas volcánicas en las tierras altas del paisaje de Los Andes; D: mosaico de plantaciones de Eucalyptus sp. en diferentes etapas de desarrollo y bosque nativo en el área preandina; E: antiguo bosque de $A$. araucana, bosque secundario y volcán en el altiplano de Los Andes; F: río, bosque secundario con presencia de árboles de Austrocedrus chilensis en el paisaje pre-Andino; G: tala rasa de la plantación forestal de P. radiata; H: mosaico de tierras agrícolas, Eucalyptus sp. plantaciones y granjas en el paisaje costero; I: $P$. radiata plantaciones en diversas etapas de desarrollo; J: cultivos agrícolas en áreas planas y bosques secundarios en las colinas de la pre cordillera de Los Andes. 
The survey was first disseminated on May $18^{\text {th }}$ of 2015 and the collection concluded on June $25^{\text {th }}$, with a total of 643 complete questionnaires. Since the survey was circulated through a link, which in turn could be resent by recipients to other people, it was not possible to know how many people received the questionnaire, or the group to which the respondent belonged. At the end of the questionnaire, an email and ID number were requested to ensure only one answer per person. Questionnaires from respondents under 18 years were disregarded.

Although internet surveys have become very popular, they are prone to well-known survey errors of non-observation or selection bias (Greenacre 2016). The population of "internet users" is dynamic and difficult to define, therefore a sampling method is challenging. For these reasons, we do not expect countrywide representativeness. The results will represent people over 18 years and internet users, which could nonetheless represent the majority of the country population given current access to internet, computers and cell phones.

The questionnaire registered personal characteristics of the interviewees, namely place of residence and years of permanency at that residence, as well as age, gender, income and education level. These attributes were selected based on previous studies, where these personal attributes have been shown to relate to landscape appreciation (e.g. Häfner et al. 2017). Given the features of the survey we do not expect a sample representative of the entire country population.

Data analysis. The design consisted of seven factors (comprising landscape and personal attributes) with their respective levels. Landscape composition as a factor had six levels corresponding to six photos (figure 2) and scenic beauty, ten levels corresponding to ten photos (figure 3). Ratings were measured on a scale of 0 to 100 by re-coding the qualitative scale originally used in the questionnaire, to elicit preferences for the different photos. Thus "I like it very much" is attached the highest values $(80-100)$, whereas "I do not like it" is attached the lowest (0-20).

Factors related to personal characteristics were education with three levels, age with three levels, monthly income with five levels, gender with two levels and place of residence with four levels (table 1).

Education ranges were grouped according to the level reached in the Chilean education system: the first level is from school (12 years) to college ( 2 years), the second university (5 years) and the third postgraduate (Master's and $\mathrm{PhD}$ ). All levels include a "studies incomplete" option.

Table 1. Personal characteristics of respondents and their categories, ordered by levels.

Características personales de los encuestados y sus categorías, ordenadas por niveles.

\begin{tabular}{|c|c|c|c|}
\hline Personal characteristics & Category & $\%$ & Mode \\
\hline \multirow{3}{*}{ Education } & School and technical level (13 years) & 8.9 & School complete \\
\hline & University (13 to 18 years) & 64.2 & Univ. Incomplete \\
\hline & Postgraduate ( $>18$ years) & 26.9 & Magister \\
\hline \multirow{3}{*}{ Age (years) } & Young adult (18-28) & 47.4 & 25 \\
\hline & Adult (29-38) & 35.8 & 34 \\
\hline & Older adult (39-72) & 16.8 & 41 \\
\hline \multirow{5}{*}{ Monthly income (US dollar) } & $<580$ & 49.3 & Not Applicable a \\
\hline & 580 to 1,160 & 24.0 & \\
\hline & 1,160 to 1,740 & 14.6 & \\
\hline & 1,740 to 2,900 & 8.7 & \\
\hline & $>2,900$ & 3.4 & \\
\hline \multirow{2}{*}{ Gender } & Male & 46.0 & \\
\hline & Female & 54.0 & \\
\hline \multirow{4}{*}{$\begin{array}{l}\text { Place of residence (Geographic } \\
\text { denominations and administrative } \\
\text { regions of Chile) }\end{array}$} & Metropolitan region & 42.4 & \\
\hline & $\begin{array}{l}\text { Northern regions (Arica and Parinacota, Tarapacá, } \\
\text { Antofagasta, Atacama, Coquimbo, Valparaíso) }\end{array}$ & 6.7 & \\
\hline & Central regions (O’Higgins, Maule, Biobío) & 28.4 & \\
\hline & $\begin{array}{l}\text { Southern regions (Araucanía, Los Ríos, Los Lagos, } \\
\text { Aisén, Magallanes) }\end{array}$ & 22.5 & \\
\hline
\end{tabular}

${ }^{a}$ We did not ask for a specific amount but for a category of income level. 
Age was calculated from year of birth. We grouped the information into three age ranges, using general age groups: "young adults" (18-28), "adults" (29-38) and "older adults" (39-72).

The five income groups were based on the most recent socioeconomic studies in Chile (CASEN 2015).

Regarding residence, we asked the region participants currently live in. Places of residence were grouped according to Chile's four main areas; North, Center, South and Metropolitan Region (where around half of the population is concentrated).

Multivariate repeated measures variance analyses (MANOVA) were applied for testing landscape composition and scenic beauty (within-subject factors) effects on responses (individual ratings), as well as the influence of personal characteristics (inter-subject factors) on those ratings (interaction effects). Repeated measures MANOVA was preferred over ANOVA, because the last rests on the assumption of sphericity and compound symmetry (Armstrong 2017). Inspection of residuals was carried out to check for normality and homoscedasticity and variables were log-transformed as necessary. The Wilks value, $F$ statistic, freedom degrees (f.d.) and $P$ values (two-tailed) are reported. All tests were performed using Stata IC14.

\section{RESULTS}

Personal characteristics of the research population. Personal characteristics were not independent from one another, as is to be expected. An independence test suggested that place of residence, age and gender act as determinants of the remaining categories. Thus, the central and southern regions presented lower than expected education and income levels under the hypothesis of independence (Chi-square $=2.391, P<0.0001$ and Chi-square $=2.2067$, $P<0.0001$, respectively). The lower age categories presented lower than expected income and education levels under the hypothesis of independence (Chi-square $=2.391$, $P<0.0001$ and Chi-square $=200.558, P<0.0001$, respectively). In turn, women displayed lower than expected income levels under independence (Chi-square $=5,766$, $P<0.0001$ ), higher than expected graduate education levels, however lower than expected school and university education levels under the hypothesis of independence (Chi-square $=458, P<0.0001)$.

General ratings for landscape composition and scenic beauty. Both landscape composition and scenic beauty showed highly significant effects $(P<0.0)$ in all tested ANOVA designs. The most highly rated photos for landscape composition included continuous vegetation cover, specifically native forests (figure 2A). The lowest rated images included photos that portrayed industrial plantations and related activities (figure 2D and 2E). Two contrasting land use types, a continuous cover of native forest and forest plantations (figure 2B), and a fine-grained mosaic of different agricultural uses (figure $2 \mathrm{~F}$ ) were similarly rated, as can be observed in figure 4A.

In the case of scenic beauty, scenes rated highest included settings with iconic forest species (A. araucana), water elements and volcanoes (figures $3 \mathrm{~A}, 3 \mathrm{E}$ and $3 \mathrm{~F}$ ). The least attractive images included scenes which depicted industrial forest plantations and related activities such as clear cutting (figures 3G and 3I). Landscapes dominated by agriculture (figure 3J) were rated higher than those dominated by plantations (figure $3 \mathrm{~J}$ ), as can be observed in figure $4 \mathrm{~B}$.

Interaction effects between landscape composition and personal characteristics. Apart from the overall effects of composition or scenic beauty and personal characteristics on landscape ratings (significance of their effects not shown here), the influence of each of these factors significantly varied across different levels of the other factors
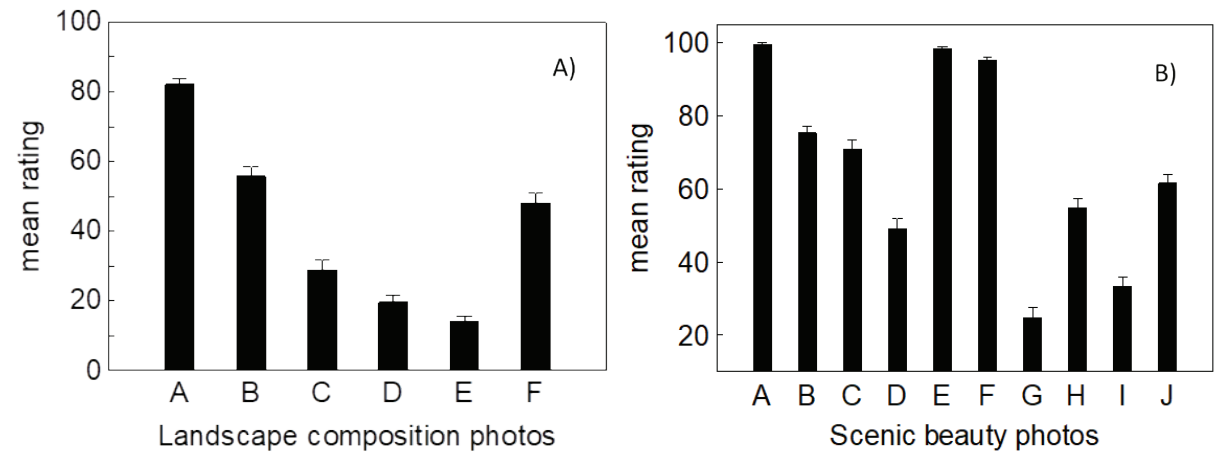

Figure 4. (A) Mean ratings for different landscape composition levels (figures 2A to 2F). (B) Mean ratings obtained from participant responses for different levels of scenic beauty (figures 3A to 3J). Whiskers indicate $95 \%$ confidence interval ranges.

(A) Valores medios de calificaciones otorgadas por los entrevistados para diferentes niveles de composición del paisaje (figuras $2 \mathrm{~A}$ a $2 \mathrm{~F}$ ). (B) Valores medios de calificaciones otorgadas por los entrevistados para diferentes niveles de belleza escénica (figuras 3A a 3J). Las barras delgadas sobre las anchas representan intervalos de confianza del $95 \%$. 
(interaction effects). The ratings of respondents for landscape compositions were modified by place of residency (Wilks $=0.947, \mathrm{~F}=2.263$, f.d. $=15, P<0.005$, figure 5A), age $($ Wilks $=0.948, \mathrm{~F}=3.376$, f.d. $=10, P<0.05$, figure 5B) and educational level (Wilks $=0.956, \mathrm{~F}=2.835$, f.d. $=$ $10, P<0.005$, figure $5 \mathrm{C}$ ). In contrast, landscape composition ratings were not modified by income or gender.

The influence of place of residence was altered in different ways according to image (figure 5A). Notably, while landscape compositions $\mathrm{A}$ and $\mathrm{E}$ were similarly rated across different places of residence, photos B, D and F were rated with increasing scores from South to North (the metropolitan region was alongside the northern and central regions category).

Regarding age, while the evaluation of landscape composition A was homogeneous across different age classes, individuals of the younger adult and adult categories tended to give lower ratings to the remaining photos contrasted with individuals over 38 years old (figure 5B). This was particularly notable for the age class of 29 to 38 years. Ratings of photos B, C and D tended to decrease from ba-

(A)

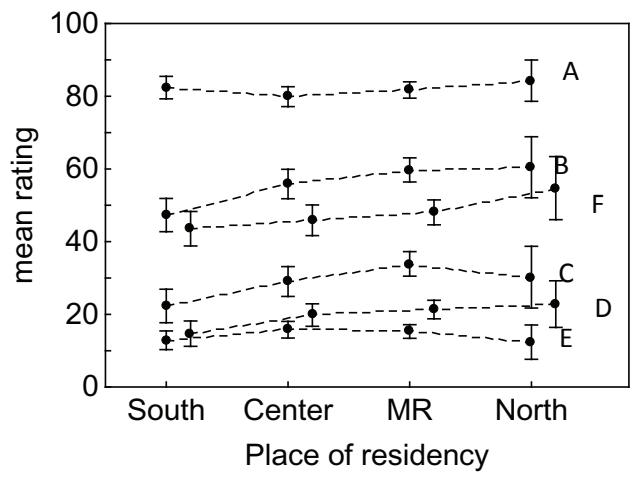

(C)

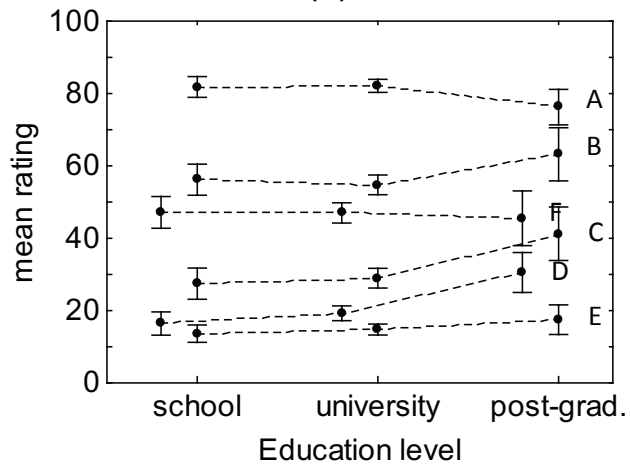

sic to middle levels of education; however, this did not occur for the remaining landscape compositions. For the graduate education category, it can also be observed that ratings of landscape compositions $\mathrm{A}$ and $\mathrm{B}$ on one side and $\mathrm{C}, \mathrm{D}$ and $\mathrm{F}$ tended to be similar (figure 5).

Interaction effects between scenic beauty and personal attributes. According to interaction tests, scenic beauty ratings varied significantly according to place of residence (Wilks $=0.9187, \mathrm{~F}=1.990$, f.d. $=27, P<0.005$, figure $6 \mathrm{~A})$, age $($ Wilks $=0.932, \mathrm{~F}=2.446$, f.d. $=18, P<0.001$, figure 6B), education (Wilks $=0.946, F=1.938$, f.d. $=18$, $P=0.01$, figure 6C), gender (Wilks $=0.956, \mathrm{~F}=3.138$, f.d. $=9, P=0.001$, figure 6D) and income (Wilks $=0.884$, $\mathrm{F}=1.473$, f.d. $=36, P<0.05$, figure $6 \mathrm{E})$.

While landscapes represented by photos A, E and F (figure 6) were homogeneously rated across different places of residence, photos I and $\mathrm{G}$ were increasingly rated from southern to central regions (figure 6A). In turn, whereas ratings of landscapes such as $\mathrm{A}$ and $\mathrm{E}$ were homogeneous across different age classes, individuals of the younger

(B)

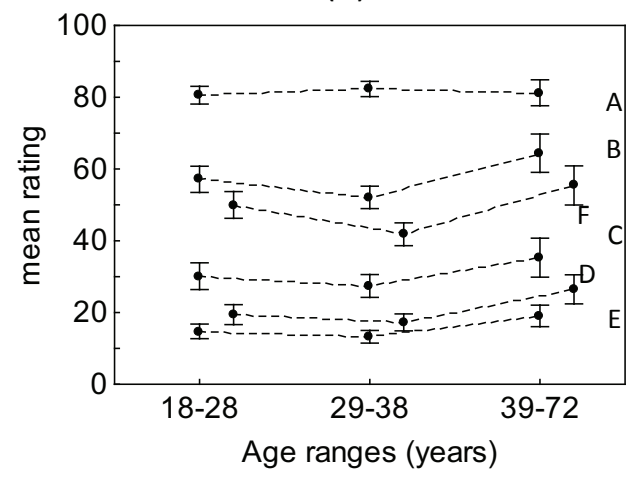

Figure 5. Interaction effects between place of residence (A), age (B) and education (C) and different landscape compositions (see figures $2 \mathrm{~A}$ to $2 \mathrm{~F})$. 
adult age class tended to give lower ratings to photos B, $\mathrm{D}$ and $\mathrm{G}$, contrasted with individuals of the older adult age class (figure 6B).

Ratings of photos $\mathrm{A}, \mathrm{E}$ and $\mathrm{F}$ were uniform across education levels, nevertheless tended to decrease from basic to high levels of education for photos D, G and I.

Instead, whereas ratings for some photos of scenic beauty (e.g. A, C, D, E, H) did not vary across gender, photo $\mathrm{B}$ was more highly valued by men than by women, and the reverse occurred for photo G (figure 6D). Finally, while some landscapes were evenly rated across income levels (e.g. A, E, F), other landscapes were unevenly valued across them (e.g. D, I) (figure 6E).

\section{DISCUSSION AND CONCLUSIONS}

These results show that ratings for different landscape compositions and levels of scenic beauty are indeed related to personal characteristics, namely education, age, income, gender and place of residence. Interaction effects between landscape compositions and personal characteristics show that preferences vary only across age, education and place of residence categories, whereas there are no interaction effects for income and gender. This notwithstanding significant interaction effects emerge among different levels of scenic beauty and all five personal characteristics tested. These results are consistent with results from other studies conducted in the northern hemisphere (Sevenant and Antrop 2010, Petrova et al. 2015).

Level of education shows significant effects on ratings for both landscape composition and scenic beauty, which could be related to an increased awareness of implications regarding landscape transformation from natural to intensively-managed landscapes, which is in line with other findings regarding preferences for restored and multifunctional landscapes (Howley et al. 2012, LindemannMatthies et al. 2010). Surprisingly, our results reveal that postgraduate education represents a shortening of mean rating distances among the selected landscapes (figure 5C), as well as among the selected scenes (figure 6C). In the first case, this is basically reflected by a lower mean rating of the more undisturbed landscapes (figure 2A) and a higher rating of exotic species-dominated landscapes by postgraduates, when compared with other respondents (figure 5C). Two scenes showing disturbed landscapes (figure $3 \mathrm{G}$ and $\mathrm{E}$ ) are ranked higher by postgraduates as compared to the rest of the respondents. Therefore, higher levels of education seem to relax the general antagonism against transformed landscapes. We did not ask participants for their professional training, so we cannot link preferences to an environmental background for example. Nonetheless, it is important to note that most respondents $(82 \%)$ declared
A)

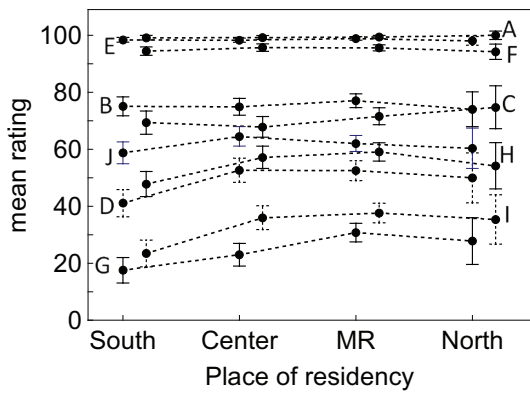

D)

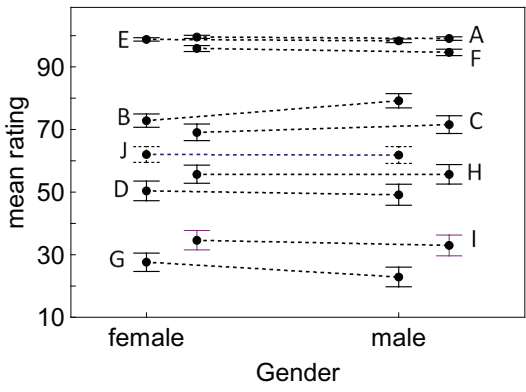

B)

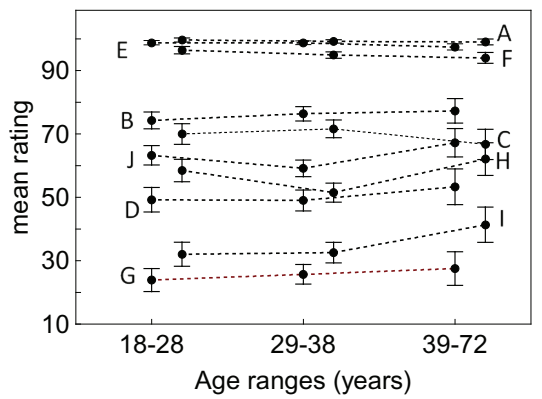

E)

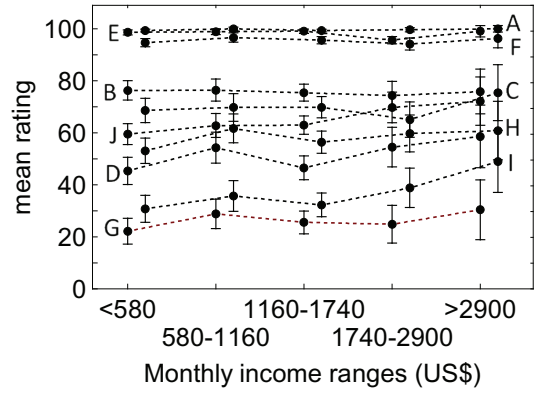

C)

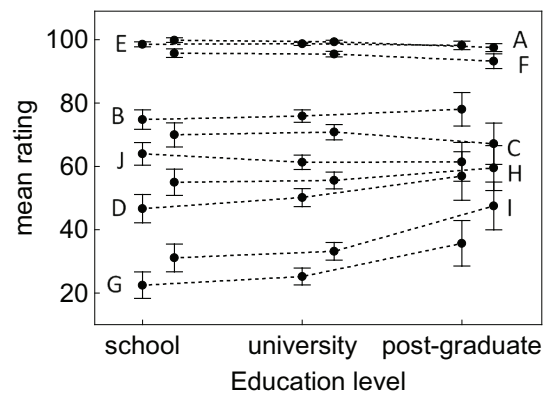

Education level

Figure 6. Interaction effects between place of residence (A), age (B), education level (C), gender (D) and income (E), and levels of scenic beauty (see photos $\mathrm{A}$ to $\mathrm{J}$ in figure 3 ).

Efectos de interacción entre el lugar de residencia (A), edad (B), nivel de educación (C), género (D) e ingreso (E) y niveles de belleza escénica (ver fotos A a J en la figura 3). 
not to be engaged in environmental activities so we might assume that preferences are not necessarily influenced by a particular environmental engagement.

Age also shows significant effects on both landscape attributes. Given that a portion of results related to education paralleled those obtained for age, age-related values could be underlying the influence of education level on rankings, or vice versa. Lower rankings of disturbed landscapes attached to the adult class of respondents may be also related to information levels and higher awareness in general. Van den Berg and Koole (2006) found that older people and people with low levels of education show lower preferences for wild nature, and that younger people with higher levels of education exhibit relatively higher preferences for wild nature. Sevenant and Antrop (2010) discovered a relationship between age and preferences for Flemish agrarian landscapes, wherein the younger the participant, the more likely they were to belong to the Antitypical Flemish/Pro-stewardship class, in which naturalness also plays an important role. Van den Berg and Koole (2006) found similar results, indicating a relatively strong preference for managed landscapes of respondents older than 50. In turn, Howley et al. (2012) and LindemannMatthies et al. (2010) reported that people with higher levels of education generally express a stronger preference than do less educated people for landscape multifunctionality, ecological restoration and wilderness in agrarian landscapes.

Results show that income has a significant effect on ratings for scenic beauty, with the highest category rating photos more evenly than in the lowest category. The effects of income have already been investigated, especially in landscape economic valuation studies; the theoretical expectation that income and preferences (as measured by willingness to pay estimates) correlate positively for specific landscape attributes, such as naturalness, has been confirmed often (e.g. van Berkel and Verburg 2014, van Zanten et al. 2014, Tagliafierro et al. 2016).

Gender exhibits the least noticeable effect on ratings. Generally, this variable has been cited as an important predictor of landscape preferences in other studies (Tveit 2009, Surová and Pinto-Correia 2016).

Place of residence, as in other studies, plays an interesting role. People from southern locations give lower ratings to landscapes dominated by plantations and agriculture, when compared to people from the central and northern regions. This might relate to the fact that the central and northern regions are dominated by highly transformed rural landscapes (i.e. intensive crops and absence of forests), and therefore any of the features contained in the photos, particularly in the case of scenic beauty, will be rated higher. On the contrary, the southern regions still maintain large areas of natural vegetation and therefore transformed landscapes, particularly those dominated by exotic plantations and related extraction activities, will receive lower ratings. Several studies corroborate that residents have different perceptions of landscapes and the role that elements play in achieving uniqueness and sense of place (Mohammad et al. 2013). For example, those individuals living in landscapes dominated by natural forests may have a systematically greater demand for enhancing biodiversity, whereas people living in farmlands and grasslands may agree in desiring additional structural elements (van Zanten et al. 2014). Van Zanten et al. (2014) conducted a meta-analysis of studies in Europe, reporting that one of the most common explanations for preference heterogeneity is the residential location of the person. Often, local residents state higher preferences for attributes associated with agricultural land cover, whereas tourists state higher preferences for attributes associated with forest and natural land cover (e.g. Soliva et al. 2010).

It is important to note however, that although statistically significant, interaction effects of respondent categories on landscape or scenic beauty levels are generally subtle. The predominant effects are inter-factor effects, related to the different images of landscape composition or scenic beauty, independent from people's characteristics. These effects reveal a general and clear preference for landscapes dominated by native vegetation, including emblematic tree species (A. araucana) and volcanoes, over landscapes dominated by plantations of exotic species or cultivated lands (figures 5 and 6).

Thus, the results of this study are consistent with the often-assumed general preference for natural landscapes as compared to human-transformed landscapes (Gobster et al. 2007, Ode et al. 2009). The recognized general preference for less-transformed landscapes underlies discussions on the "ecological aesthetics" of natural landscapes, suggesting that ecological quality and perceived aesthetic beauty are correlated (Gobster et al. 2007). The ecological perspective is that unmodified natural ecosystems hold the highest aesthetic value (Ode et al. 2009). The ecological perspective relies on biological principles of ecosystem management as given, and then affirms that human preferences should be consistent with those principles. Therefore, some authors pose the existence of some "objective" or intrinsic aesthetic qualities in the environment (Uzzell 1991).

For example, various authors have agreed that the tourism and recreation phenomenon is heavily associated with aesthetic experience of landscapes (van Berkel and Verburg 2014), which may have important implications for tourism planning. However, whereas studies of landscape perception have had relevant implications for landscape management in Europe (van der Zanden et al. 2016), in developing countries such recognition is far from being achieved. In the words of Tempesta and Vecchiato (2015) "landscape policy must include specific measures aimed at the protection, management and planning of landscapes to be adopted to satisfy the aspirations of the public with regard to the landscape elements of their surroundings". From this definition, it is understood that the visual quality 
of a landscape must be judged by the general public and not solely by experts (Sevenant and Antrop 2010, Tempesta and Vecchiato 2015).

It is important to mention, however, that this study does not aim at providing unbiased estimates of population parameters but focuses on exploring the relationships between variables to understand the characteristics of people that influence their preferences on certain attributes in the landscape. To this end, the methodological procedure was aimed at capturing the greatest possible variability of responses, which are nonetheless limited by the access to internet and social networks.

Despite this, the information provided in the present study is a first step towards understanding landscape preferences and attitudes toward the environment among various groups of people and assessing the trade-offs of natural landscape transformation. Public planners and private protected area networks at various levels work with questions involving this type of issue. Additionally, tourism operators can use this type of information to target and promote highly rated elements for potential destinations.

\section{ACKNOWLEDGEMENTS}

This research has been supported by Grants FONDECYT 1140531 and 1151187 and FONDAP 15110009.

\section{REFERENCES}

Armstrong RA. 2017. Recommendations for analysis of repeated-measures designs: testing and correcting for sphericity and use of MANOVA and mixed model analysis. Ophthalmic and Physiological Optics 37(5): 585-593.

Brown P. 2013. Education, opportunity and the prospects for social mobility. British Journal of Sociology of Education 34(5-6): 678-700.

Casado-Arzuaga I, M Onaindia, I Madariaga, PH Verburg. 2014. Mapping recreation and aesthetic value of ecosystems in the Bilbao Metropolitan Greenbelt (northern Spain) to support landscape planning. Landscape Ecology 29: 1393-1405.

CASEN (Caracterización Socioeconómica Nacional, CL). 2015. Una medición de la pobreza moderna y transparente para Chile. 29 p. (Presentación de resultados encuesta CASEN 2013).

Dachary-Bernard J, T Rambonilaza. 2012. Choice experiment, multiple programmes contingent valuation and landscape preferences: How can we support the land use decision making process? Land Use Policy 29(4): 846-854.

Gobster PH, JI Nassauer, TC Daniel, G Fry. 2007. The shared landscape: What does aesthetics have to do with ecology? Landscape Ecology 22(7): 959-972.

Greenacre ZA. 2016. The Importance of Selection Bias in Internet Surveys. Open Journal of Statistics 6: 397-404.

Häfner K, I Zasada, BT van Zanten, F Ungaro, M Koetse, A Piorr. 2017. Assessing landscape preferences: a visual choice experiment in the agricultural region of Märkische Schweiz, Germany. Landscape Research. 16 p. DOI: 10.1080/01426397.2017.1386289
Howley P, S Hynes, CO Donoghue. 2012. Countryside preferences: Exploring individuals' willingness to pay for the conservation of the traditional farm landscape. Landscape Research 37(6): 703-719.

Kaplan R, S Kaplan. 1989. The Experience of Nature: A Psychological Perspective. Cambridge, UK. Cambridge University Press. 370 p.

Laurie IC. 1975. Aesthetic factors in visual evaluation. In Zube EN, RO Brush, JG Fabos eds. Landscape Assessment: Values, Perceptions and Resources. Stroudsburg, PA, USA. p. 102-117.

Lee KC, YH Son. 2017. Exploring Landscape Perceptions of Bukhansan National Park According to the Degree of Visitors' Experience. Sustainability 9(8): 1306.

Lindemann-Matthies P, X Junge, D Matthies. 2010. The influence of plant diversity on people's perception and aesthetic appreciation of grassland vegetation. Biological Conservation 143(1): 195-202.

Lock K, L Cole. 2011. Public Perceptions of Landscapes and Ecosystems in the UK. A report to the Department for Environment, Food and Rural Affairs. London, UK. Policy Studies Institute. $90 \mathrm{p}$.

Mohammad NMN, M Saruwono, SY Said, WAHW Hariri. 2013. A Sense of Place within the Landscape in Cultural Settings. Procedia-Social and Behavioral Sciences 105:506-512.

Muñoz-Pedreros A. 2004. La evaluación del paisaje: una herramienta de gestión ambiental. Revista Chilena de Historia Natural 77: 139-156.

Muñoz-Pedreros A 2017. The visual landscape: an important and poorly conserved resource. Ambiente \& Sociedade 20(1): 165-182.

Nielsen AB, E Heyman, G Richnau. 2012. Liked, disliked and unseen forest attributes: Relation to modes of viewing and cognitive constructs. Journal of Environmental Management 113: 456-466.

Ode A, G Fry, MS Tveit, P Messager, D Miller. 2009. Indicators of perceived naturalness as drivers of landscape preference. Journal of Environmental Management 90(1): 375-383.

Petrova EG, YV Mironov, Y Aoki, H Matsushima, S Ebine, K Furuya, A Petrova, N Takayama, H Ueda. 2015. Comparing the visual perception and aesthetic evaluation of natural landscapes in Russia and Japan: cultural and environmental factors. Progress in Earth and Planetary Science 2(6): 1-12.

Schirpke U, E Tasser, U Tappeiner. 2013. Predicting scenic beauty of mountain regions. Landscape and Urban Planning 111: 1-12.

Scholte SSK, AJA van Teeffelen, PH Verburg. 2015. Integrating socio-cultural perspectives into ecosystem service valuation: a review of concepts and methods. Ecological Economics 114: 67-78.

Sevenant M, M Antrop. 2010. The use of latent classes to identify individual differences in the importance of landscape dimensions for aesthetic preference. Land Use Policy 27(3): 827-842.

Soliva R, J Bolliger, M Hunziker. 2010. Differences in preferences towards potential future landscapes in the Swiss Alps. Landscape Research 35(6): 671-696.

Surová D, T Pinto-Correia. 2016. A landscape menu to please them all: Relating users' preferences to land cover classes in the Mediterranean region of Alentejo, Southern Portugal. Land Use Policy 54: 355-365. 
Tagliafierro C, M Boeri, A Longo, WG Hutchinsona. 2016. Stated preference methods and landscape ecology indicators: An example of transdisciplinarity in landscape economic valuation. Ecological Economics 127: 11-22.

Tempesta T, D Vecchiato. 2015. Testing the difference between experts' and lay people's landscape preferences. Aestimum 66: June 1-41.

Tveit MS. 2009. Indicators of visual scale as predictors of landscape preference; a comparison between groups. Journal of Environmental Management 90(9): 2882-2888.

Tveit M, A Ode, G Fry. 2006. Key concepts in a framework for analysing visual landscape character. Landscape Research 31(3): 229-255.

Uzzell DL. 1991. Environmental psychological perspectives on landscape. Landscape Research 16(1): 3-10.

Van Berkel DB, PH Verburg. 2014. Spatial quantification and valuation of cultural ecosystem services in an agricultural landscape. Ecological Indicators 37: 163-174.

Van den Berg AE, SL Koole. 2006. New wilderness in the
Netherlands: An investigation of visual preferences for nature devel-opment landscapes. Landscape and Urban Planning 78(4): 362-372.

van der Wal R, D Miller, J Irvine, S Fiorini, A Amar, S Yearley, R Gill, N Dandy. 2014. The influence of information provision on people's landscape preferences: A case study on understorey vegetation of deer-browsed woodlands. Landscape and Urban Planning 124: 129-139.

van der Zanden EH, C Levers, PH Verburg, T Kuemmerle. 2016. Representing composition, spatial structure and management intensity of European agricultural landscapes: A new typology. Landscape and Urban Planning 150: 36-49.

van Zanten B, P Verburg, M Koetse, P van Beukering. 2014. Preferences for European agrarian landscapes: A meta-analysis of case studies. Landscape and Urban Planning 132: 89101.

Wang R, J Zhao, Z Liu. 2016. Consensus in visual preferences: The effects of aesthetic quality and landscape types. Urban Forestry \& Urban Greening 20: 210-217. 